\title{
Author Correction: Glucose homeostasis is regulated by pancreatic $\beta$-cell cilia via endosomal EphA-processing
}

Francesco Volta, M. Julia Scerbo, Anett Seelig, Robert Wagner, Nils O’Brien (1), Felicia Gerst, Andreas Fritsche, Hans-Ulrich Häring, Anja Zeigerer (1), Susanne Ullrich \& Jantje M. Gerdes (D)

Correction to: Nature Communications https://doi.org/10.1038/s41467-019-12953-5, published online 12 December 2019.

In the original version of this article the Figure Legends in the Supplementary Information were inadvertently omitted. The HTML of the article has been updated to include the correct version of the Supplementary Information. The original version of the article also incorrectly referenced Supplementary Figures 2D and Supplementary Figure 2E, which were cited as Figure 2D and Figure 2E. This has been corrected in both the PDF and HTML versions of the Article.

Published online: 03 August 2021

\section{Additional information}

Supplementary information The online version contains supplementary material available at https://doi.org/10.1038/s41467-021-24865-4.

(c) Open Access This article is licensed under a Creative Commons Attribution 4.0 International License, which permits use, sharing, adaptation, distribution and reproduction in any medium or format, as long as you give appropriate credit to the original author(s) and the source, provide a link to the Creative Commons license, and indicate if changes were made. The images or other third party material in this article are included in the article's Creative Commons license, unless indicated otherwise in a credit line to the material. If material is not included in the article's Creative Commons license and your intended use is not permitted by statutory regulation or exceeds the permitted use, you will need to obtain permission directly from the copyright holder. To view a copy of this license, visit http://creativecommons.org/licenses/by/4.0/.

(C) The Author(s) 2021 